\title{
Analysis of the Level of Critical Thinking Skills of Students in Biological Materials at Muhammadiyah High School in Palembang City
}

\author{
Sulton Nawawi*, Nizkon, Ahmad Trian Azhari \\ Department of Biology Education, Faculty of Teacher Training and Education, Muhammadiyah University of Palembang, Indonesia
}

Received December 9,2019; Revised December 30,2019; Accepted February 25, 2020

Copyright $\subseteq 2020$ by authors, all rights reserved. Authors agree that this article remains permanently open access under the terms of the Creative Commons Attribution License 4.0 International License

\begin{abstract}
Critical thinking skills are competencies that must be trained in students because these skills are essential to compete in the life of the 21st century. The purpose of this study is to determine the level of critical thinking skills of students in biological material in Muhammadiyah High School throughout Palembang. This research is a qualitative descriptive study; the population and sample in this study were students of class XI IPA Muhammadiyah High School in Palembang. The research instrument used was a test of critical thinking skills as many as 20 multiple choice questions of semester XI biology material 1 . The data obtained will be analyzed quantitatively. Quantitative analysis is used to analyze students' test results. The results showed the level of critical thinking skills of students in Muhammadiyah High Schools throughout Palembang City varied; the exceptionally high category was obtained at $1.85 \%$, top category amounting to $14.5 \%$, medium category $66.6 \%$, low category $16.4 \%$ and category very low at $0.5 \%$. The results of this study provide information on the profile of students 'critical thinking skills in Muhammadiyah High Schools throughout Palembang City with the highest moderate category so that teachers are expected to be able to design learning process activities that can empower students' critical thinking skills.
\end{abstract}

Keywords Critical Thinking, Biology Material

\section{Introduction}

Education is a benchmark of the progress of a nation, so it is not wrong if the development of education in Indonesia must continue to be improved along with the progress of civilization [1]. Educational progress in the 21st century contains various kinds of competencies or expertise that students may need to have, one of which is: students' ability to think critically and solve problems, be able to think critically, laterally, and systematically, especially in the context of solving a problem [2].

To win the competition in the 21st century, students need to improve their thinking skills; especially higher-order thinking or critical thinking skills. Critical thinking is a skillful and active interpretation and evaluation of observation and communication, information, and argumentation [3]. The similar opinion expressed by [4]. Critical thinking is defined as the ability to judge one's mind on the results of interpretation, analysis, evaluation, inference, and explanation to produce decisions that consider concepts, methodologies, criteria, and contexts.

High school students need the ability to think critically, especially high schools in the city of Palembang, and this is to help and find a concept of learning because to face the era of globalization, there is intense competition between nations. A nation that can master some knowledge, technology, and skills will be the winner. This is consistent with the opinion of [5], [6]. Critical thinking skills play a role in equipping students with dealing effectively with social, scientific, and practical problems in the future.

However, according to [7], students' critical thinking skills in Indonesia are said to be still low, which can be seen from the low number of students who answered correctly in the 2012 Program for International Student Assessment (PISA) and ranks 64 out of 65 countries. In the PISA study 2012, Indonesian students are weak in solving problems that require Higher Order Thinking Skills (HOTS) such as questions related to solving problems related to real life. According to the results of Boleng (2014), critical thinking skills in class XI high school students in Samarinda in the 2011/2012 academic year is still low. The low critical thinking skills is one of them because students are not accustomed to working on problems based on critical thinking. The teacher has not fully integrated the 
indicators of critical thinking in the problem. Research Nawawi \& Wijayanti (2018) The odd UAS questions used in 8 Islamic-based high schools in the Seberang Ulu area of Palembang have not yet maximized the critical thinking aspect, namely interpretation of 7,02\%; analysis of $1,89 \%$; $0 \%$ evaluation; inference $5,52 \%$; an explanation of $11,37 \%$; and self-regulation of $1,75 \%$.

Important because according to [10], students who can think critically can learn problems systematically, face millions of challenges in an organized way, formulate innovative questions, and design original solutions. They will get used to distinguishing between truth and lies, appearance and reality, facts and opinions, knowledge, and beliefs. They will naturally build arguments using reliable evidence and logical logic, and they will get used to building imaginative relationships between different things, seeing unexpected possibilities, and thinking in new ways about familiar problems.

Biology is concerned with finding out and understanding nature systematically so that it is not only the mastery of gathering knowledge in the form of factors, concepts, principles but also a process of discovery [11]. Therefore, the ability to think students critically is needed in the process of quality biology learning for the realization of a generation that can compete in the era of globalization.

The purpose of learning biology in content standards states that students can foster scientific attitudes that are honest, objective, open, resilient, critical, and can work together with others. The purpose and function of biology subjects listed in the content standard are to foster scientific attitudes that are not easy to believe without the support of empirical observations, understanding biological concepts and their application to solving problems in everyday life. To achieve these objectives, learning by developing a critical thinking attitude is important because professional and quality human resources will be created if the knowledge is explored more deeply by developing a culture of critical thinking. Teaching critical thinking skills can help students to become critical thinkers effectively.

\section{Research Methods}

This research is descriptive. The purpose of this descriptive study is to determine the level of critical thinking skills of students. The research will be conducted at Muhammadiyah High Schools in Palembang, namely Muhammadiyah 2 High Schools, Muhammadiyah 3 High Schools, Muhammadiyah 4 High Schools, Muhammadiyah 5 High Schools, Muhammadiyah 6 High Schools, and Palembang Muhammadiyah 8 High Schools. The population in this study were students of class XI IPA Muhammadiyah high school in Palembang.

Sampling in this study was carried out by simple random sampling. This sample was taken by random drawing from all XI IPA classes of Muhammadiyah High School in Palembang, which is known to assign one class in each Muhammadiyah High School to be used as research samples.

The instrument for testing the level of critical thinking skills of students is in the form of question sheets given to students. The test used is a test to determine the level of critical thinking skills of students. Tests for critical thinking skills in biology class XI are in odd semester 2017-2018. The questions given are multiple-choice questions totaling 19 questions of critical thinking tests that are based on the source of the National Examination (UN) questions from 2010-2016, selection of new student admissions (SPMB) in 2004, 2007, joint selection of entering state universities (SNMPTN) in 2009, 2011 and selection of new national-level student admissions (SBMPTN) in 2015 each question represent a sub-indicator of critical thinking. The instrument grid refers to indicators of critical thinking skills from [4].

The data obtained will be analyzed quantitatively. Data analysis was carried out quantitatively, which aims to determine the percentage of students' critical thinking abilities. Quantitative analysis is used to analyze student test results.

Recapitulation of the results of the critical skills tests obtained by each student is equipped with all indicators and sub-indicators of critical thinking skills. The score obtained is changed in the form produced according to the following formula:

$$
=\frac{\Sigma \text { Ability }=(\text { score obtained })}{\Sigma \text { ideal score }} \times 100 \%
$$

The interpretation of critical thinking skills is made by converting percentage values into the ability category scale.

Table 1. Skill Category Scale

\begin{tabular}{|c|c|}
\hline Percentage (\%) & Category \\
\hline $90-100$ & Very high \\
\hline $80-89$ & High \\
\hline $65-79$ & Is \\
\hline $55-64$ & Low \\
\hline $0-54$ & Very low \\
\hline
\end{tabular}

Finally, determine the average percentage of the overall student score that reflects the indicators of students' critical thinking.

\section{Results and Discussion}

\subsection{Results}

The results of tests on the level of critical thinking skills in high school students of Muhammadiyah in Palembang can be seen in Table 2 . 
Table 2. Results of Critical Thinking Tests of Muhammadiyah High School Students in Palembang

\begin{tabular}{|c|c|c|c|c|c|c|}
\hline No & School & Very low (\%) & Low (\%) & Moderat (\%) & High (\%) & Very High (\%) \\
\hline 1. & SMA Muhammadiyah 2 Palembang & 0 & 14,8 & 59,3 & 22,2 & 3,7 \\
\hline 2. & SMA Muhammadiyah 3 Palembang & 0 & 12,5 & 75 & 12,5 & 0 \\
\hline 3. & SMA Muhammadiyah 4 Palembang & 3,4 & 31 & 58,6 & 6,9 & 0 \\
\hline 4. & SMA Muhammadiyah 5 Palembang & 0 & 14,3 & 74,3 & 11,3 & 0 \\
\hline 5. & SMA Muhammadiyah 6 Palembang & 0 & 0 & 66,7 & 25,9 & 7,4 \\
\hline 6. & SMA Muhammadiyah 8 Palembang & 0 & 26,1 & 65,7 & 8,7 & 0 \\
\hline & Total & 3,4 & 98,7 & 399,6 & 87,5 & 11,1 \\
\hline & Average & $\mathbf{0 , 5}$ & $\mathbf{1 6 , 4}$ & $\mathbf{6 6 , 6}$ & $\mathbf{1 4 , 5}$ & $\mathbf{1 , 8 5}$ \\
\hline
\end{tabular}

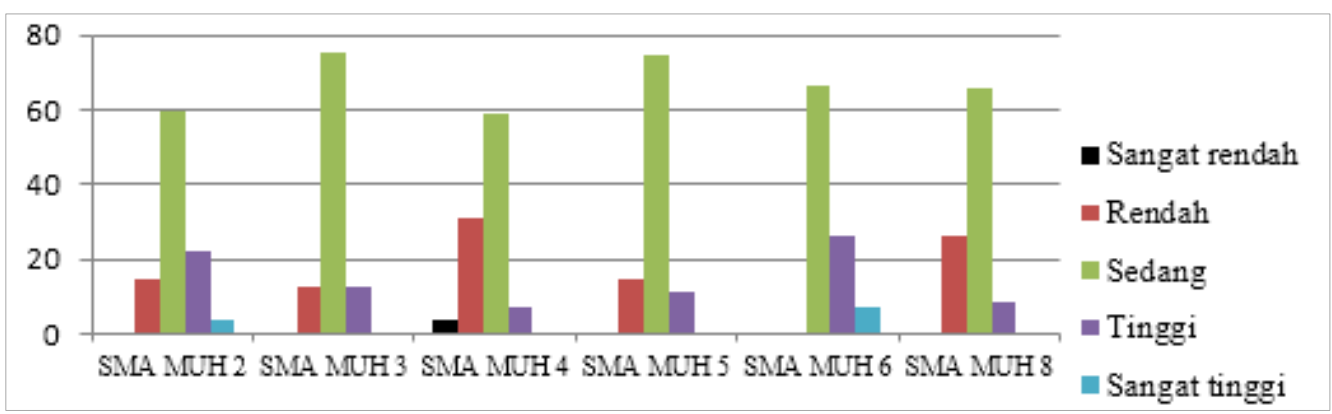

Figure 1. Comparison of Critical Thinking Skill Levels of Muhammadiyah High School Students in Palembang City

In Table 2, the results of students' critical thinking tests can also be presented in the form of a histogram, as shown in Figure 1.

Figure 1. Comparison of Critical Thinking Skill Levels of Muhammadiyah High School Student Based on Table 2 and Figure 1 that the results of tests of critical thinking levels of students to very low level there is only one school namely SMA Muhammadiyah 4 Palembang which is 3,4\%. Low levels were obtained by almost all schools except Muhammadiyah 6 Palembang High Schools, moderate levels were obtained evenly by all Muhammadiyah High Schools Palembang with a percentage of 59,3\% Muhammadiyah 2 High Schools, 75\% Muhammadiyah 3 High Schools, 58.6\% Muhammadiyah 4 High Schools, 74,3\% High Schools Muhammadiyah 5, 66,7\%
Muhammadiyah 6 SMA, and 65,7\% Muhammadiyah 8 SMA Palembang. High levels were obtained for all Muhammadiyah Palembang high schools, and for very high levels there were only two schools namely Muhammadiyah 2 SMA with a percentage of 3,7\% and Muhammadiyah 6 Palembang High School with a percentage of 7,4\%.s in Palembang City.

3.1.1. Percentage Results of Per-indicator Critical Thinking Skill Level Test in Muhammadiyah High Schools in Palembang City

The following percentage of indicators of students' critical thinking skills test is seen in Table 3 below: 
Table 3. Results of Critical Thinking Tests for Per-indicator Students in Muhammadiyah High Schools in Palembang City

\begin{tabular}{|c|c|c|c|c|c|c|c|}
\hline No & School & $\begin{array}{c}\text { Interpretation } \\
(\%)\end{array}$ & Analysis (\%) & $\begin{array}{c}\text { Evaluation } \\
(\%)\end{array}$ & $\begin{array}{c}\text { Conclusion } \\
(\%)\end{array}$ & $\begin{array}{c}\text { Explanation } \\
(\%)\end{array}$ & $\begin{array}{c}\text { Self-Management } \\
(\%)\end{array}$ \\
\hline & $\begin{array}{c}\text { SMA Muhammadiyah } \\
\text { 2 Palembang }\end{array}$ & 70,3 & 75,9 & 62,9 & 76,5 & 69,6 & 70,3 \\
\hline $\begin{array}{c}\text { SMA Muhammadiyah } \\
\text { 3 Palembang }\end{array}$ & 47,2 & 75 & 83,3 & 77,8 & 77,8 & 61,1 \\
\hline $\begin{array}{c}\text { SMA Muhammadiyah } \\
\text { 4 Palembang }\end{array}$ & 60 & 62,9 & 68,9 & 72,4 & 68,3 & 60,3 \\
\hline $\begin{array}{c}\text { SMA Muhammadiyah } \\
\text { 5 Palembang }\end{array}$ & 63,6 & 71,4 & 76 & 66,6 & 69,7 & 67,1 \\
\hline $\begin{array}{c}\text { SMA Muhammadiyah } \\
\text { 6 Palembang }\end{array}$ & 74,1 & 69,4 & 68,5 & 72,8 & 80,7 & 81,5 \\
\hline $\begin{array}{c}\text { SMA Muhammadiyah } \\
\text { 8 Palembang }\end{array}$ & 64,1 & 71,7 & 63 & 68,1 & 73 & 47,8 \\
\hline
\end{tabular}

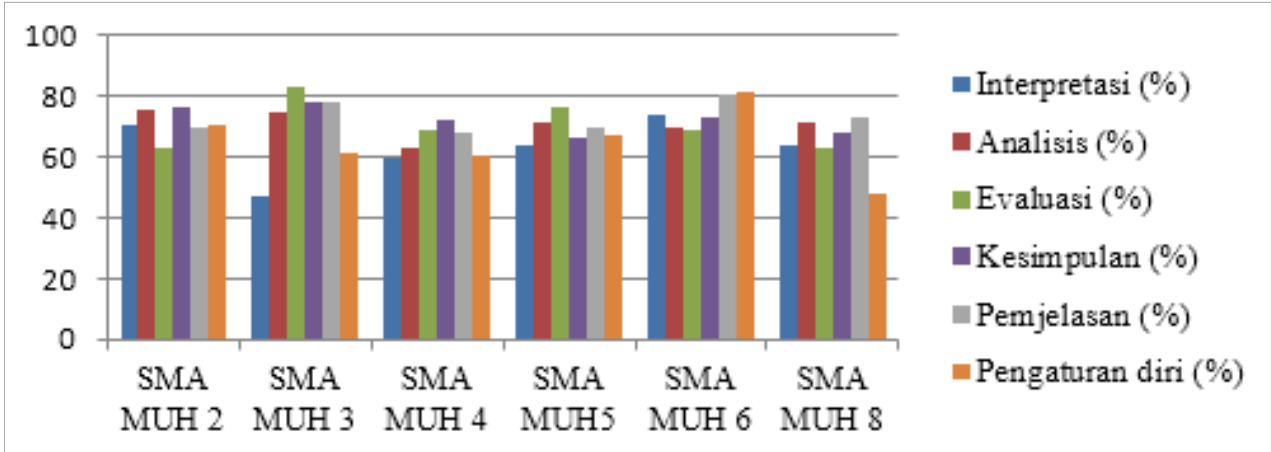

Figure 2. Comparison of the per-indicator percentage for each school in the Muhammadiyah high school in the city Palembang

Comparison of the results of the percentage per-indicator of students' critical thinking can be seen in Figure 2.

Based on Table 3 and Figure 2 above, the percentage of critical thinking skills level per indicator can be seen. The table above shows that there are six indicators of critical thinking. First, Muhammadiyah 2 Senior High School Palembang, the percentage of test scores for interpretation indicators was $70,3 \%$, analysis $75,9 \%$, evaluation $63,9 \%$, conclusion $76,5 \%$, explanation $69,9 \%$, and self-regulation $70.3 \%$. The following percentage of Muhammadiyah 3 High Schools in Palembang, the test scores for the interpretation indicator is $47,2 \%, 75 \%$ analysis, $83,3 \%$ evaluation, $77,8 \%$ conclusion, $77.8 \%$ explanation, and $61.1 \%$ self-regulation. The third percentage of Muhammadiyah 4 High Schools in Palembang, the test scores for interpretation indicators are $60 \%$, analysis $62.9 \%$, evaluation $68,9 \%$, conclusion $72.4 \%$, explanation $68.3 \%$, and self-regulation $60,3 \%$. The fourth percentage of Muhammadiyah 5 Senior High School Palembang test scores for the interpretation indicator is $63,6 \%$, analysis $71,4 \%$, evaluation $76 \%$, conclusion $66,6 \%$, explanation $69,7 \%$, and self-regulation $67.1 \%$. The fifth percentage of Muhammadiyah High School 6 Palembang test scores for indicator interpretation is $63,6 \%$, analysis $71,4 \%$, evaluation $76 \%$, conclusion interpretation indicator $74,1 \%$, analysis $69,4 \%$, evaluation $68.5 \%$, conclusion $72.8 \%$, explanation $80.7 \%$, and self-regulation $81,5 \%$. The last percentage of Muhammadiyah Senior High School 8 Palembang test scores for interpretation indicators was $64.1 \%$, analysis $71,7 \%$, evaluation $63 \%$, conclusion $68,1 \%$, explanation $73 \%$, and self-regulation $47,8 \%$. the percentage for each school in the Muhammadiyah high school in the city Palembang. Overall indicator of critical thinking: Interpretation 63,21\%, Analysis 71,05\%, Evaluation 70,43\%, Conclusion 72,36\%, Explanation $73,18 \%$, Self-Management $64,68 \%$.

\subsection{Discussion}

Based on the results of the study, obtained profiles of the level of critical thinking skills of Muhammadiyah high school students in Palembang City can be seen. Starting from the very high level of the six Muhammadiyah High Schools in Palembang studied, there were two schools namely Muhammadiyah 2 Palembang High School from 27 students who took the test only 3,7\% (one person) students, and Muhammadiyah 6 Palembang High School from 27 students who took the test only 7,4\% (two) students. For the high level, evenly obtained all Muhammadiyah high schools in Palembang City, the largest with a percentage of $25,9 \%$ (7 people) 
Muhammadiyah 6 Palembang High School students and the second with a percentage of 22,2\% (6 people) Muhammadiyah 2 High School Palembang students.

Being in the medium category level or quite critical evenly all the Muhammadiyah high schools in Palembang City. Muhammadiyah 2 Palembang SMA obtained results with a percentage of 59,3\% (16 people) from 27 students who took the test, Muhammadiyah 3 Palembang High School obtained results with percentage of $75 \%$ (6 people) of 9 students who took the test, Muhammadiyah 4 Palembang High School obtained results with a percentage of 58,6\% (17 people) students from 29 students who took the test, Muhammadiyah 5 Palembang High School obtained a percentage of 74, 3\% (26 students) of 35 students who took the test, Muhammadiyah 6 Palembang High School obtained results with a percentage of $66,7 \%$ (18 people) students from 27 students who took the test, and Muhammadiyah 8 Palembang High School obtained results with a percentage of $65,7 \%$ (15 students) out of 23 students took the test.

Seen the most prominent results obtained in Muhammadiyah 6 Palembang High School, the results obtained were that no students were included in the category of critical thinking skills level very low and low, also for the very high and high levels of this high school the largest or many, in the observations of researchers when the research took place, before the atmosphere of a busy class where many students were noisy and playing. After the researcher enters the class and explains a little the purpose of the researcher coming, students slowly begin to pay attention, and then the class begins to control, the researcher continues to spread the test questions to all students. When working on the test questions that are given, it seems that they are working on it seriously, think about and examine the questions first then answer them correctly. Similar opinion according to Johnson (2002), students who are able to think critically will get used to distinguishing between truth and lies, appearance and reality, facts and opinions, knowledge and beliefs, and in solving problems they will examine seriously and build an argument using reliable evidence and reasonable logic.

There are still some students who have low levels of critical thinking skills, and obtained in almost all schools except Muhammadiyah 6 Palembang High School and the largest in Muhammadiyah 4 Palembang High School as many as 31\% (nine) students from 29 students who took the test and Muhammadiyah 8 High School Palembang as many as $26,1 \%$ (six people) of 23 students who took the test. For very low levels there is only one school, Muhammadiyah 4 Palembang High School, which is 3,4\% (one person), student.

Muhammadiyah 4 Palembang High School got the most students in the low and very low categories. This is due to the fact that most students tend to be less active in paying attention to the concept of understanding when the researcher explains. Carefulness and accuracy in answering the test must also be considered, because the tendency of students after working is not re-examined, such as: seeing the questions that are missed or not answered, and revisiting the results that they previously erased but did not refill. This is also explained by Arnyana (2006) that the causes of low critical thinking skills can also have implications on low student achievement, inaccuracy and inadvertence when solving problems, and also on the learning process that does not provide opportunities for students to empower their thinking skills and be actively involved in the learning process.

In addition to the above factors, it can be observed that researchers at six Muhammadiyah high schools in Palembang city studied some students who had a fearful or anxious attitude before accepting the problem. Because when the test is distributed, some students immediately want to give up without first seeing and analyzing the tests that have been given, the students are not motivated in working on the questions in earnest and also the physical condition of some students begins to decline because before working on the test questions they follow school lessons. Mental should be possessed by students that are ready to accept all problems encountered so that it will train them to think in a better direction and come out critical in solving a problem.

Based on the analysis of the level of critical thinking skills of Muhammadiyah high school students in Palembang City, almost all students have enough categories or moderate levels of critical thinking based on the results of the proposed tests. In the test we can see the thinking patterns of diverse students, there are those who do it quickly, seriously but slowly until the time is finished they have not entirely answered the questions, there are those who work on the questions seriously but joking with their fellow students, but there are also those who work with seriously, think about and examine the questions first and then answer them correctly. Therefore, based on the analysis of the researchers, it can be concluded that the majority of Muhammadiyah high school students in the city of Palembang have a level of critical thinking with a moderate or sufficiently critical category level. This is what is analyzed because critical is a pattern of thinking with reference to the truth. Critical thinking must also be supported by understanding a concept, however, to answer a question or problem, a person must still be guided by something right (understanding the correct concept) so that he can solve problems correctly and adequately instead of adding new problems.

The level of students' critical thinking skills can also be seen through the analysis of indicators. In this case, the indicator of critical thinking consists of 6 indicators according to Facione (2013), namely interpretation, analysis, evaluation, conclusions, explanations, and self-regulation. Based on the results of the percentage analysis of critical thinking indicators that have been done, the percentage of data obtained per-indicator for 
Muhammadiyah High Schools in Palembang City.

Based on Table 2 and Figure 2, the percentage per-indicator level of critical thinking skills of students, obtained data on the test as follows. First, on the percentage of interpretation indicators, Muhammadiyah 6 Palembang High School got the highest result at $74.1 \%$, and Muhammadiyah 3 Palembang High School got the lowest result at $47,2 \%$. The second percentage in the analysis indicators, Muhammadiyah 2 Palembang High School got the highest result, which was 75,9\%, and Muhammadiyah 4 Palembang High School got the lowest result, which was $62,9 \%$. The third percentage in the evaluation indicators, Muhammadiyah 3 Palembang High School, got the highest result, which was 83,3\% and Muhammadiyah 2 Palembang High School got the lowest result, which was $62,9 \%$. The fourth percentage on the conclusion indicator, Muhammadiyah 3 Palembang High School, got the highest result of 77,8\%, and Muhammadiyah 5 Palembang High School got the lowest result of $66,6 \%$. The fifth percentage in the explanatory indicator, Muhammadiyah 6 Palembang High School, got the highest result at $80.7 \%$, and Muhammadiyah 4 Palembang High School got the lowest result at 68,3\%. Moreover, lastly on self-regulation indicators, Muhammadiyah 6 Palembang High School got the highest result, which was $81,5 \%$, and Muhammadiyah 8 Palembang High School got the lowest result, which was $47,8 \%$. Overall indicator of critical thinking; Interpretation 63,21\%, Analysis 71,05\%, Evaluation 70,43\%, Conclusion $72,36 \%$, Explanation 73,18\%, Self-Management $64,68 \%$.

Based on the analysis of indicators that have been carried out, it can be seen that each school gets a percentage of critical thinking skills tests per indicator varies. With this, students are always required to develop or improve their critical thinking skills. Overall indicator Students who can deduce are more competent in drawing conclusions or hypotheses based on facts, judgments, beliefs, principles, concepts, or representations. Students who have evaluation skills are more competent in assessing the credibility of statements and representations from others and assessing the logical strength of statements, descriptions, or questions [13]. Indicators can be used to convince and use insight criteria to support decisions [14]. Self-regulation plays a role in directing oneself to assist students in managing their thoughts, behavior, and emotions in order to successfully direct learning experiences to achieve goals [15]. This is in line with research Elliot \& Dweck (2005) that students who have high achievements have a strategy in self-regulation, especially in learning. Self-regulation is vital for the learning process because self-regulation can have an important impact on academic results [17]. This can help students make better study habits and strengthen their learning abilities [18]. Students who have analytical skills are better able to identify the relationship between statements, questions, concepts, or descriptions to express beliefs, judgments, or reasons. Students who can interpret are better able to understand and express meaning about experiences, beliefs, data, rules, and others during the learning process [13].

To train students to be able to develop critical thinking skills, students must take care of their physique because they have a fit physique that will affect the accuracy in thinking before school sets that students must motivate themselves to learn well so that they gain knowledge from their teachers; finally, students must begin to develop skills of analyzing, evaluating, solving problems and concluding. Research Brooke (2006) explains that critical thinking can be improved by presenting cases in learning so that students are encouraged to use their critical thinking skills when analyzing and solving available cases. In line with the results of the study Hanson \& Wolfskill (2000) states that problem-solving through teamwork can improve students' skills in critical thinking, reduce misconceptions, seek information and construct understanding actively and skillfully provide high-level reasons. The purpose of practicing critical thinking skills to students is to prepare students to be critical thinkers, be able to solve problems, and become independent thinkers, so they can face life, avoid indoctrination, fraud, brainwashing, resolve any problems encountered, and make decisions correctly and responsibly [21].

\section{Conclusions}

Based on the research that has been done, it can be concluded that the level of critical thinking skills of students in Biology material in the Muhammadiyah High Schools in Palembang City varies, ranging from very low levels to very high levels. The average value of critical thinking skills in the very high-level category is $1.85 \%$, the high category is $14.5 \%$, the medium category is $66.6 \%$, the low category is $16.4 \%$, and the very low category is $0.5 \%$.

\section{REFERENCES}

[1] M. D. Sagap, Sarjan N. Husain, M.P, “Analisis Pemahaman Konsep Biologi Menggunakan Pilihan Ganda Beralasan Dalam Materi Pokok Sel Pada Siswa Kelas XI IPA SMA Negeri 1 Dampal Selatan,” J. e-Jipbiol, vol. 2, no. 3, p. 2, 2014.

[2] R. Kono and H. D. Mamu, "Pengaruh Model Problem Based Learning (PBL) Terhadap Pemahaman Konsep Biologi Dan Keterampilan Berpikir Kritis Siswa Tentang Ekosistem Dan Lingkungan Di Kelas X Sma Negeri 1 Sigi,” J. Sains dan Teknol. Tadulako, vol. 5, no. 4, pp. 28-38, 2016.

[3] A. Fisher, "Berpikir kritis,” Berpikir Kritis Sebuah Pengatar. 2014.

[4] P. A. Facione, Critical Thinking, What It Is and Why I Counts. California: California Academic Press, 2013. 
[5] Liliasari, "Model Pembelajaran IPA Untuk Meningkatkan Keterampilan Berpikir Tingkat Tinggi Calon Guru Sebagai Kecenderungan Baru pada Era Globalisasi,” J. Pengajaran Mat. dan Ilmu Pengetah. Alam, vol. 2, no. 1, pp. 54-66, 2001.

[6] L. G. Snyder, L. G. Snyder, M. J. Snyder, and M. J. Snyder, "Teaching Critical Thinking and Problem-Solving Skills," Delta Pi Epsilon. J., vol. L, no. 2, pp. 90-100, 2008.

[7] M. E. Kinasih, T. Jalmo, and B. Yolida, "Pengaruh Model Discovery Learning Terhadap Keterampilan Berpikir Kritis Siswa,” J. Bioterdidik Wahana Ekspresi Ilm., vol. 3, no. 10, pp. 50-60, 2015.

[8] D. T. Boleng, "Pengaruh Model Pembelajaran Cooperative Script dan Think-Pair-Share terhadap Keterampilan Berpikir Kritis, Sikap Sosial, dan Hasil Belajar Kognitif Biologi Siswa SMA Multietnis,” J. Pendidik. Sains, vol. 2, no. 2, pp. 76-84, 2014.

[9] S. Nawawi and T.F. Wijayanti, Pengembangan Asesmen Biologi Berbasis Keterampilan Berpikir Kritis Terintegrasi Nilai Islam,”Jurnal Inovasi Pendidikan IPA, vol.4, no.2, p.136-148, 2018.

[10] Johnson, Contextual teaching and learning: What it is and why it's here to stay. Corwin Press, 2002.

[11] P. Siahaan, Prastowo, "Pengaruh pemanfaatan lingkungan sekitar sekolah terhadaphasil belajar siswa pada materi pokok ekosistem,” in Prosiding Seminar Nasional Biologi dan Pembelajarannya, 2014, pp. 597-605.

[12] I. Arnyana, "Pengaruh Penerapan Strategi Pembelajaran Inovatif pada Pelajaran Biologi Terhadap Kemampuan Berpikir Kreatif Siswa SMA,” J. Pendidik. dan Pengajaran IKIP Negeri Singaraja, vol. 3, no. 6, pp. 496-515, 2006.

[13] J. D. Ricketts and R. D. Rudd, "Critical Thinking Skills of selected Youth Leaders: The Efficacy of Critical Thinking Dispositions, Leadership, And Academic Performance,” J. Agric. Educ., vol. 46, no. 1, pp. 32-43, 2005.

[14] P. A. Facione, “Critical Thinking: A Statement of Expert Consensus for Purposes of Educational Assessment and Instruction Executive Summary “The Delphi Report,” Calif. Acad. Press, vol. 423, no. c, pp. 1-19, 1990.

[15] S. Zumbrunn, J. Tadlock, and E. D. Roberts, "Encouraging Self-Regulated Learning in the Classroom: A Review of the Literature,” 2011.

[16] A. J. Elliot and C. S. Dweck, "Competence and Motivation: Competence as the Core of Achievement Motivation," Handbook of competence and motivation. pp. 3-12, 2005.

[17] B. J. Zimmerman, "Investigating Self-Regulation and Motivation: Historical Background, Methodological Developments, and Future Prospects,” Am. Educ. Res. J., vol. 45, no. 1, pp. 166-183, 2008.

[18] C. A. Wolters, "Regulation of motivation: Evaluating an underemphasized aspect of self-regulated learning," Educ. Psychol., vol. 38, pp. 189-205, 2003.

[19] S. L. Brooke, "Using the Case Method to Teach Online Classes: Promoting Socratic Dialogue and Critical Thinking Skills,” Int. J. Teach. Learn. High. Educ., vol. 18, no. 2, pp. 142-149, 2006.
[20] D. Hanson and T. Wolfskill, "Process Workshops - A New Model for Instruction,” J. Chem. Educ., vol. 77, no. 1, p. 120, 2000.

[21] W. Redhana and D. Liliasari, “Program Pembelajaran Keterampilan Berpikir Kritis pada Topik Laju Reaksi untuk Siswa SMA,” Forum Kependidikan, vol. 27, no. 2, pp. 103-112, 2008. 